\title{
Evaluasi Kematangan Pascapanen Pisang Barangan untuk Menentukan Waktu Panen Terbaik Berdasarkan Akumulasi Satuan Panas
}

\section{Postharvest Maturity Evaluation of Banana cv Barangan to Determinate The Best Harvest Time Based on Heat Unit}

\author{
Winarso Drajad Widodo*, Ketty Suketi, dan Rizky Rahardjo \\ Departemen Agronomi dan Hortikultura, Fakultas Pertanian, Institut Pertanian Bogor \\ (Bogor Agricultural University), Jl. Meranti, Kampus IPB Darmaga, Bogor 16680, Indonesia \\ Telp.\& Faks. 62-251-8629353 e-mail agrohort@apps.ipb.ac.id \\ *Penulis Korespondensi: wd_widodo@yahoo.com \\ Disetujui : 19 September 2018 / Published Online 06 Mei 2019
}

\begin{abstract}
Banana is climacteric fruit with a short shelf life. Postharvest handling of Bananas aimed to keep the quality and storability. Degree of ripeness when harvested affect on the quality of the bananas. This research aimed to analyze effect of difference harvest time to postharvest maturity criteria and to determine the best harvest time of Barangan banana based on the accumulation of heat unit. The experiment was conducted in PT. Perkebunan Nusantara VIII Kebun Parakan Salak, Sukabumi, West Java and Postharvest Laboratory, Department of Agronomy and Horticulture, Faculty of Agriculture, Bogor Agricultural University. The experiment was conducted with completely randomized block design with 5 harvest times: 68, 73, 78, 83, and 88 days after anthesis (DAA). Each treatment was applied to 5 bunches as replication. Barangan banana can be harvested at 78 DAA when the accumulation of heat unit reach $1200-1250^{\circ} \mathrm{C}$ day within live storage as 13-14 days after harvested (DAH). Barangan banana fruit with older harvest time more quickly reach postharvest maturity than fruit with young harvest time. Harvest time treatment at 68-88 DAA affected the weight of fruit, value of weight loss, skin hardness, vitamin C, total soluble solid (TSS), total titritable acidity (TTA), and TSS/TTA ratio, but doesn't affect on the value pulp hardness and edible part.
\end{abstract}

Keywords: anthesis, chemical quality, heat unit, physical quality, shelf life

\section{ABSTRAK}

Buah pisang termasuk buah klimakterik dengan umur simpan pendek. Penanganan pascapanen buah pisang bertujuan untuk mempertahankan kualitas dan umur simpan buah. Tingkat kematangan buah ketika dipanen dapat mempengaruhi kualitas buah. Penelitian ini bertujuan untuk mempelajari pengaruh perbedaan umur petik terhadap kriteria kematangan pascapanen dan menentukan umur petik terbaik pisang Barangan berdasarkan akumulasi satuan panas. Percobaan dilaksanakan di PT. Perkebunan Nusantara VIII Kebun Parakan Salak, Sukabumi, Jawa Barat dan Laboratorium Pascapanen, Departemen Agronomi dan Hortikultura, Fakultas Pertanian, Institut Pertanian Bogor. Percobaan menggunakan rancangan kelompok lengkap teracak dengan 5 perlakuan umur petik: 68, 73, 78, 83, dan 88 hari setelah antesis (HSA). Setiap perlakuan diterapkan pada 5 tandan sebagai ulangan. Buah pisang Barangan dapat dipanen pada umur petik 78 HSA dengan akumulasi satuan panas sebesar $1200-1250{ }^{\circ} \mathrm{C}$ hari dan umur simpan mencapai 13-14 hari setelah panen (HSP). Buah pisang Barangan dengan umur petik lebih tua lebih cepat mencapai kematangan pascapanen dibandingkan buah dengan umur petik muda. Perlakuan umur petik 68-88 HSA mempengaruhi bobot buah, susut bobot, kekerasan kulit buah, kandungan vitamin C, padatan terlarut total (PTT), asam terlarut total (ATT), dan rasio PTT/ATT, namun tidak mempengaruhi kekerasan daging buah dan edible part.

Kata kunci: antesis, kualitas fisik, kualitas kimia, satuan panas, umur simpan 


\section{PENDAHULUAN}

Pisang merupakan buah yang banyak dikonsumsi masyarakat dalam bentuk segar maupun olahan. Pisang memberikan kontribusi terbesar terhadap produksi buah nasional yang mencapai $34.65 \%$ dari produksi total buah nasional. Produksi buah nasional pisang menunjukkan peningkatan dalam tahun 20112015. Produksi pisang nasional pada tahun 2015 mencapai 7.29 juta ton dengan 5 produsen utama yaitu Lampung, Jawa Timur, Jawa Barat, Jawa Tengah, dan Bali (Kementan, 2016).

Permasalahan penting dalam budidaya pisang yaitu penentuan umur petik yang berdampak pada kualitas buah pisang (Cahyono, 2009). Penentuan umur petik dengan menghitung jumlah hari setelah bunga mekar hingga panen masih menimbulkan keragaman dalam pemasakannya. Buah pisang termasuk golongan buah klimakterik yang mengalami peningkatan laju respirasi setelah buah dipanen sehingga buah mudah rusak (Kuntarsih, 2012). Luka fisik pada buah pisang yang dijual mengakibatkan nilai jual pisang rendah dan berdampak pada rendahnya pendapatan petani (Suryana, 2006). Waktu pemanenan buah yang tidak tepat dapat menyebabkan kualitas buah kurang baik. Buah yang dipanen terlalu muda akan memiliki kualitas yang kurang baik ketika matang, sedangkan buah yang dipanen terlalu tua memiliki daya simpan rendah.

Penentuan waktu panen umumnya menggunakan beberapa indikator yaitu perbandingan antara daging buah dan kulit, jumlah hari setelah pembungaan, menghilangnya sudut-sudut pada setiap buah, mengeringnya daun, dan kerapuhan ujung tandan (Pantastico, 1986). Metode tersebut tidak memperhitungkan suhu harian rata-rata yang diperoleh tanaman selama proses budidaya sehingga menimbulkan keragaman dalam pemasakannya. Permasalahan tersebut mendorong pengembangan metode pemanenan dengan mempertimbangkan energi panas yang dibutuhkan tanaman untuk reaksi fisiologi selama pertumbuhan dan perkembangan mulai dari antesis hingga panen atau disebut metode satuan panas (heat unit). Penentuan umur petik dengan metode ini memperhitungkan suhu rata-rata aktual yang diperoleh tanaman selama di lahan hingga tanaman tersebut mencapai kematangan optimal untuk dipanen.

Penelitian mengenai kriteria kematangan pascapanen yang telah dilakukan oleh Sutowijoyo dan Widodo (2013) menunjukkan bahwa umur petik terbaik untuk penanganan pascapanen dalam rangka memperpanjang umur simpan pada pisang
Raja Bulu adalah 95 HSA, dan 110 HSA pada pisang Kepok. Rahayu et al. (2014) menyatakan bahwa pisang Raja Bulu yang dipetik pada 85 HSA (satuan panas $1305{ }^{\circ} \mathrm{C}$ hari) dapat disimpan selama 10 hari. Hasil penelitian Yulyana (2015) menunjukkan bahwa umur petik terbaik untuk penanganan pascapanen dalam rangka memperpanjang masa simpan buah pisang Mas Kirana adalah 40-50 HSA (satuan panas 576.5$725.5{ }^{\circ} \mathrm{C}$ hari). Prasetyo (2016) menyatakan bahwa umur petik terbaik pisang Mas Kirana adalah $600{ }^{\circ} \mathrm{C}$ hari. Penelitian dilanjutkan pada jenis pisang Barangan dengan tujuan untuk menentukan umur petik terbaik berdasarkan akumulasi satuan panas.

Penelitian ini bertujuan untuk mempelajari pengaruh perbedaan umur petik terhadap kriteria kematangan pascapanen dan menentukan umur petik terbaik pisang Barangan berdasarkan akumulasi satuan panas. Dasar pemikiran tersebut yang menjadi latar belakang penulis untuk melakukan penelitian penentuan waktu panen pisang Barangan berdasarkan kriteria kematangan pascapanen buah dari beberapa umur petik.

\section{BAHAN DAN METODE}

Bahan yang digunakan dalam percobaan ini adalah buah pisang Barangan anakan keempat pada sisir ke 3 dengan umur petik 68, 73, 78, 83, dan 88 hari setelah antesis (HSA). Bahan-bahan lain meliputi: kain saring, kertas koran, air tawas, fungisida berbahan aktif Iprodion $50 \%$, larutan phenolphtalein, aquades, $\mathrm{NaOH} 0.1 \mathrm{~N}$, serta Iodin $0.01 \mathrm{~N}$. Alat-alat yang digunakan antara lain termometer maksimum minium, penetrometer, refraktometer, timbangan analitik, kosmotektor, wadah plastik, labu takar, buret, dan gelas ukur.

Percobaan dilakukan dengan Rancangan Kelompok Lengkap Teracak (RKLT) faktor tunggal yaitu umur petik pisang. Percobaan terdiri atas lima perlakuan umur petik: $68,73,78,83$, dan 88 hari setelah antesis (HSA). Setiap perlakuan terdiri dari 5 ulangan, sehingga terdapat 25 satuan percobaan. Setiap satuan percobaan terdiri atas satu tandan, setiap tandan diambil sisir ke 3 dari pangkal tandan, dan setiap sisir diambil 8 jari buah dari bagian tengah sisir untuk pengujian fisik dan kimia buah.

Percobaan diawali dengan kegiatan penandaan tanaman pisang di kebun untuk mendapatkan buah pisang dengan umur petik sesuai dengan 5 taraf perlakuan percobaan yang ditentukan. Penandaan dilakukan dengan menandai tanaman pisang yang sedang berbunga antesis pada setiap perlakuan. Pengukuran suhu harian rata-rata dilakukan untuk mengetahui 
akumulasi satuan panas yang diterima tanaman pisang selama masa generatif dengan menggunakan termometer maksimum minimum. Setelah mencapai umur petik sesuai dengan masing-masing taraf perlakuan, bauh pisang dipanen, kemudian dibersihkan dalam bak cuci berisi air tawas. Selanjutnya buah disemprot dengan fungisida berbahan aktif Iprodion 50\% untuk mengendalikan dan mencegah cendawan tumbuh pada kulit buah. Buah pisang kemudian dikeringanginkan dan diberi label sebagai penanda satuan percobaan lalu dikemas dalam wadah kardus. Setelah itu, buah diangkut ke Laboratorium Pascapanen, Departemen Agronomi dan Hortikultura, Fakultas Pertanian, Institut Pertanian Bogor untuk dilakukan pengamatan pascapanen buah. Pengamatan pascapanen buah pisang dilakukan pada 8 jari bagian tengah sisir.

Pengamatan dilakukan pada 10 parameter yang mengacu pada penelitian yang telah dilaksanakan oleh Sutowijoyo dan Widodo (2013), Rahayu et al. (2014), Yulyana (2015), dan Prasetyo (2016). Parameter pengamatan pada penelitian ini adalah: (1) suhu harian rata-rata; (2) warna kulit buah; (3) susut bobot; (4) kelunakan buah; (5) laju respirasi; (6) umur simpan; (7) bagian buah yang dapat dimakan (edible part); (8) padatan terlarut total (PTT); (9) asam titrasi total (ATT); dan (10) kandungan vitamin C.

\section{Suhu Harian Rata-rata}

Pengamatan suhu harian rata-rata dilakukan setiap hari di lapangan untuk menentukan satuan panas yang diterima buah pisang Barangan. Pengamatan dilakukan dengan mengukur suhu maksimum dan suhu minimum dengan menggunakan termometer maksimum minimum setiap hari selama proses perkembangan buah dari bunga antesis hingga pemanenan. Termometer diletakkan di lokasi pertanaman pisang Barangan dengan posisi sejajar mata pengamat. Pengukuran satuan panas menggunakan suhu dasar $10{ }^{\circ} \mathrm{C}$ mengacu pada Nakasone dan Paull (1998). Pertumbuhan dan perkembangan tanaman pisang dapat terhambat pada suhu $10{ }^{\circ} \mathrm{C}$. Menurut Parthasarathi et al. (2013) suhu dasar merupakan suhu lingkungan minimal suatu tanaman untuk dapat tumbuh dan berkembang.

$$
\text { Satuan Panas }=\sum_{i=0}^{\mathrm{i}} \frac{\operatorname{Tmax}_{\mathrm{i}}-\operatorname{Tmin}_{\mathrm{i}}}{2}-b
$$

Keterangan:

$\mathrm{T}$ max $=$ Suhu maksimum hari ke-i $\left({ }^{\circ} \mathrm{C}\right)$

$\mathrm{T} \min =$ Suhu minimum hari ke-i $\left({ }^{\circ} \mathrm{C}\right)$

$\mathrm{b}=$ Suhu dasar $\left(10^{\circ} \mathrm{C}\right)$

\section{Warna Kulit Buah}

Pengamatan warna kulit buah dilakukan dengan menggunakan indeks skala warna kulit buah. Indeks skala warna kulit buah pisang digunakan sebagai parameter untuk mengukur tahapan pematangan buah pisang secara visual. Pengamatan warna kulit buah pisang Barangan mengacu pada indeks skala warna buah pisang Mas Kirana (Yulyana, 2015). Derajat kekuningan kulit buah tersebut dinilai dengan angka 1 sampai 6.

\section{Umur Simpan}

Umur simpan digunakan untuk mengetahui perbandingan lama masa simpan buah pada setiap umur petik dalam proses mempertahankan kesegaran buah. Umur simpan buah ditentukan sebagai masa simpan buah setelah dipanen hingga mencapai skala warna 6 dengan melihat parameter perubahan fisik buah pisang.

\section{Susut Bobot}

Pengukuran susut bobot buah dilakukan dengan menggunakan timbangan analitik. Pengukuran ini dilakukan dengan membandingkan bobot 8 jari buah pisang sebelum penyimpanan dan akhir saat buah mencapai indeks skala warna 6. Rumus yang digunakan yaitu:

$$
\% \text { Susut Bobot }=\frac{\text { Bobot awal-Bobot akhir }}{\text { Bobot awal }} \times 100 \%
$$

\section{Kelunakan Buah}

Kelunakan buah diukur dengan menggunakan alat penetrometer. Pengukuran dilakukan pada buah pisang yang belum dikupas kulitnya dan pada daging buah pisang. Pengukuran dengan penetrometer dilakukan pada pada tiga bagian buah, yaitu ujung, tengah, dan pangkal buah. Ketiga data yang diperoleh kemudian diambil rata-ratanya.

\section{Laju Respirasi}

Pengukuran laju respirasi dilakukan setiap hari sejak buah pisang dipanen hingga mencapai skala warna 6 . Pengukuran laju respirasi dilakukan dengan mengukur laju produksi gas $\mathrm{CO}_{2}$ yang dihasilkan buah pisang setelah diinkubasi selama 3 jam. Buah pisang diinkubasi di dalam wadah tertutup yang dihubungkan dengan 2 pipa plastik sebagai saluran pengeluaran $\mathrm{CO}_{2}$ yang kemudian diukur menggunakan kosmotektor. Laju emisi $\mathrm{CO}_{2}$ dihitung dengan rumus:

$$
\mathrm{L}=\frac{\mathrm{V} \times \mathrm{K} \times 1.76}{\mathrm{~W} \times \mathrm{B}}
$$


Keterangan:

$\mathrm{L}=$ Laju respirasi $\left(\mathrm{ml} \mathrm{CO}_{2} \mathrm{~kg}^{-1} \mathrm{jam}^{-1}\right)$

$\mathrm{V}=$ Volume udara bebas dalam stoples $(\mathrm{ml})$

$\mathrm{K}=$ Kadar emisi $\mathrm{CO}_{2}(\%)$

$\mathrm{W}=$ Waktu inkubasi (jam)

$\mathrm{B}=$ Bobot bahan $(\mathrm{kg})$

Nilai 1.76 merupakan konstanta gas

\section{Bagian Buah yang Dapat Dimakan (Edible Part)}

Pengukuran bagian buah yang dapat dimakan dilakukan dengan menggunakan timbangan analitik. Pengukuran bagian buah yang dapat dimakan diukur dengan menimbang bobot buah pisang sebelum dikupas dan setelah dikupas. Bagian buah yang dapat dimakan dihitung dengan menggunakan rumus:

$$
\% \text { Edible part }=\frac{\text { Bobot daging buah }}{\text { Bobot buah }} \times 100 \%
$$

\section{Padatan Terlarut Total}

Kandungan PTT diukur dengan menghancurkan daging buah pisang, kemudian diambil sarinya dengan menggunakan kertas saring. Sari buah yang telah diperoleh diteteskan pada lensa refraktometer. Kadar PTT dapat dilihat pada alat dalam satuan ${ }^{\circ}$ Brix (g sukrosa $100 \mathrm{~g}$ bahan $^{-1}$ ) mengacu pada Bradley (2010).

\section{Asam Tertitrasi Total}

Kandungan asam tertitrasi total (ATT) diukur berdasarkan netralisasi ekstrak buah oleh basa kuat $\mathrm{NaOH}$. Kandungan ATT diukur dengan menghancurkan bahan $25 \mathrm{~g}$ daging buah terlebih dahulu, kemudian bahan yang telah hancur dimasukkan ke dalam labu takar $100 \mathrm{ml}$ dan ditambahkan aquades sampai tera lalu disaring. Setelah disaring, larutan diambil sebanyak $25 \mathrm{ml}$ dan ditambahkan indikator fenolftalein sebanyak 3 tetes, lalu dititrasi dengan $\mathrm{NaOH} 0.1 \mathrm{~N}$ hingga larutan berubah warna menjadi merah muda. Menurut Sadler dan Murphy (2010) kandungan ATT dihitung dengan menggunakan rumus:

$$
\operatorname{ATT}(\%)=\frac{\mathrm{ml} \mathrm{NaOH} \times \mathrm{fp} \times 0.1 \mathrm{~N} \mathrm{x} \mathrm{BE}}{\text { Bobot contoh }(\mathrm{mg})} \times 100
$$

Keterangan:

Fp : Faktor pengenceran $\left(100 \mathrm{ml} 25 \mathrm{ml}^{-1}\right)$

BE : Bobot ekuivalen asam malat

\section{Kandungan Vitamin C}

Kandungan vitamin $\mathrm{C}$ diukur dengan melakukan titrasi menggunakan larutan Iodin $0.01 \mathrm{~N}$ dan indikator larutan amilum. Indikator amilum dibuat dengan melarutkan $1 \mathrm{~g}$ amilum ke dalam $100 \mathrm{ml}$ aquades yang dididihkan.
Pengukuran kandungan vitamin $\mathrm{C}$ dilakukan dengan cara menghancurkan bahan $25 \mathrm{~g}$ daging buah terlebih dahulu, kemudian bahan yang telah hancur dimasukkan ke dalam labu takar $100 \mathrm{ml}$ dan ditambahkan aquades sampai tera lalu disaring. Larutan yang telah disaring diambil sebanyak $25 \mathrm{ml}$ diberi tiga tetes indikator larutan amilum kemudian dititrasi dengan Iodin. Titrasi dilakukan sampai terbentuk warna biru tua yang stabil. Menurut Pegg et al. (2010) kandungan vitamin $\mathrm{C}$ dihitung menggunakan metode $\mathrm{AOAC}$ 967.21 dengan rumus:

$$
\text { Vitamin C }(\mathrm{mg} / 100 \mathrm{~g})=\frac{\mathrm{ml} \text { Iodin } \times 0.01 \mathrm{~N} \text { x fp x BE }}{\text { Bobot contoh }(\mathrm{g})} \times 100
$$

Keterangan:

Fp : Faktor pengenceran $\left(100 \mathrm{ml} 25 \mathrm{ml}^{-1}\right)$

BE : Bobot ekuivalen asam askorbat

Data yang diperoleh dianalisis dengan uji $\mathrm{F}$ menggunakan aplikasi SAS versi 9.4 dilanjutkan dengan uji Duncan Multiple Range Test (DMRT) pada taraf $5 \%$.

\section{HASIL DAN PEMBAHASAN}

\section{Laju Respirasi dan Umur Simpan}

Umur simpan buah merupakan salah satu faktor yang dapat menentukan kualitas buah agar tetap terjaga sejak panen hingga sampai kepada konsumen. Penentuan waktu panen yang tepat dapat memperpanjang umur simpan. Umur simpan pisang Barangan diukur dengan mengamati perubahan warna kulit buah setelah panen hingga mencapai warna kuning penuh. Perubahan warna kulit buah pisang Barangan disajikan pada Gambar 1.

Gambar 1 menunjukkan bahwa warna kulit buah secara bertahap berubah menjadi kuning selama penyimpanan. Perubahan warna kulit buah pisang Barangan dibagi menjadi 6 skala warna. Kulit buah pisang Barangan saat dipanen berwarna hijau penuh (skala 1), kemudian muncul sedikit warna kuning (skala 2). Setelah itu warna kulit buah menjadi hijau kekuningan (skala 3). Warna kuning terus melebar hingga mendominasi warna hijau dengan perbandingan $7: 3$ (skala 4).

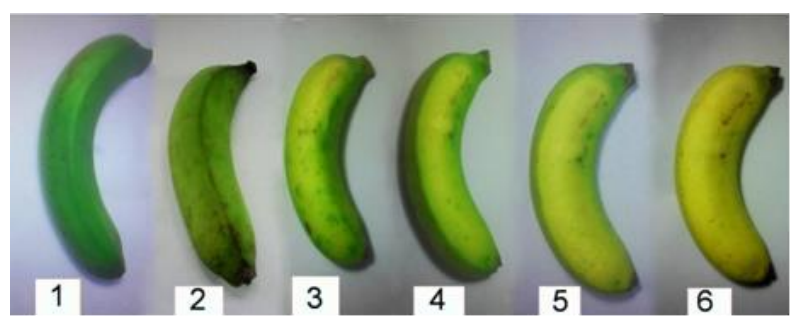

Gambar 1. Indeks skala warna buah pisang Barangan pada beberapa tingkat kematangan 
Kulit buah semakin menguning hingga warna hijau hanya terdapat pada ujung dan pangkal buah (skala 5) dan kemudian mencapai warna kuning penuh (skala 6).

Buah pisang Barangan pada percobaan ini dipanen pada umur $68,73,78,83$, dan 88 HSA. Akumulasi satuan panas pada setiap perlakuan diukur sejak tanaman antesis hingga panen. Hasil pengamatan umur simpan pada setiap perlakuan umur petik disajikan pada Tabel 1.

Tabel 1.Umur simpan pisang Barangan pada beberapa perlakuan umur petik

\begin{tabular}{ccc}
\hline $\begin{array}{c}\text { Umur Petik } \\
(\text { HSA })\end{array}$ & $\begin{array}{c}\text { Satuan Panas }\left({ }^{0} \mathrm{C}\right. \\
\text { hari) }\end{array}$ & $\begin{array}{c}\text { Umur Simpan } \\
\text { (HSP) }\end{array}$ \\
\hline 68 & 1075.62 & $15.8 \mathrm{a}$ \\
73 & 1153.87 & $14.0 \mathrm{ab}$ \\
78 & 1230.87 & $13.2 \mathrm{~b}$ \\
83 & 1310.88 & $9.2 \mathrm{c}$ \\
88 & 1384.17 & $9.8 \mathrm{c}$ \\
\hline
\end{tabular}

Keterangan: Angka yang diikuti huruf berbeda pada kolom yang sama berbeda nyata berdasarkan hasil DMRT pada taraf $\alpha=5 \%$; HSA: Hari setelah antesis; HSP: Hari setelah panen

Akumulasi satuan panas pisang Barangan pada umur petik 68-88 HSA sebesar 1075.62$1384.17{ }^{\circ} \mathrm{C}$ hari. Penghitungan akumulasi satuan panas dilakukan selama fase generatif pisang Barangan, yaitu saat tanaman memasuki fase antesis hingga panen. Wang (1960) menyatakan bahwa penentuan akumulasi satuan panas suatu tanaman harus dilakukan pada beberapa lokasi dengan ketinggian tempat yang berbeda sesuai dengan ketinggian tempat tumbuh tanaman tersebut. Selain itu, penentuan akumulasi satuan panas pada fase pertumbuhan dengan fase perkembangan tanaman harus dilakukan secara terpisah.

Hasil percobaan menunjukkan bahwa perlakuan umur petik mempengaruhi umur simpan buah pisang Barangan. Umur simpan buah dengan perlakuan umur petik $68 \mathrm{HSA}\left(1075.62{ }^{\circ} \mathrm{C}\right.$ hari) lebih lama dari umur simpan buah dengan perlakuan umur petik 78,83 , dan 88 HSA. Perlakuan umur petik 68 dan 73 HSA (1075.62$1153.87{ }^{\circ} \mathrm{C}$ hari) menghasilkan buah dengan umur simpan yang tidak berbeda yaitu 14-15.8 HSP. Selama pertumbuhan dan perkembangan, tanaman memerlukan sejumlah panas untuk memperoleh energi bagi proses-proses fisiologinya. Salah satu proses fisiologi tersebut adalah respirasi yang dapat diukur dengan mengamati emisi $\mathrm{CO}_{2}$ yang dihasilkan. Santoso dan Purwoko (1995) menyatakan bahwa emisi $\mathrm{CO}_{2}$ merupakan pemecahan oksidatif terhadap bahan kompleks yang terdapat dalam sel seperti tepung, gula dan asam amino menjadi molekul sederhana seperti
$\mathrm{CO}_{2}$, air serta energi dan molekul lainnya yang dapat digunakan oleh sel untuk reaksi sintesis selanjutnya.

Pengukuran laju respirasi dilakukan dengan mengukur kadar $\mathrm{CO}_{2}$ yang dihasilkan buah pisang setelah melalui proses inkubasi. Buah pisang diinkubasi dalam wadah inkubasi dengan volume 6 L selama 3 jam, kemudian diukur kadar emisi $\mathrm{CO}_{2}$ yang dihasilkan sehingga didapat laju respirasi. Selama proses pemasakan, laju produksi gas $\mathrm{CO}_{2}$ pada buah pisang cenderung meningkat dan mencapai titik puncak pada waktu tertentu, kemudian menurun setelah proses pemasakan selesai (Gambar 2). Hasil penelitian menunjukkan bahwa puncak klimakterik perlakuan umur petik $68,73,78,83$, dan 88 HSA berturut-turut terjadi pada $15,13,11,7$, dan 4 hari setelah panen (HSP). Menurut Pradhana et al. (2013) puncak klimakterik menunjukkan bahwa buah telah mengalami fase pematangan. Fase pematangan buah pisang ditandai dengan perubahan warna buah pisang menjadi kuning merata dan aroma matang pisang lebih pekat. Widjanarko (2012) menyatakan bahwa respirasi merupakan perombakan bahan yang kompleks dalam sel (pati, gula, dan asam- asam organik) dengan bantuan oksigen menjadi molekul yang sederhana seperti $\mathrm{CO}_{2}$, air, dan energi.

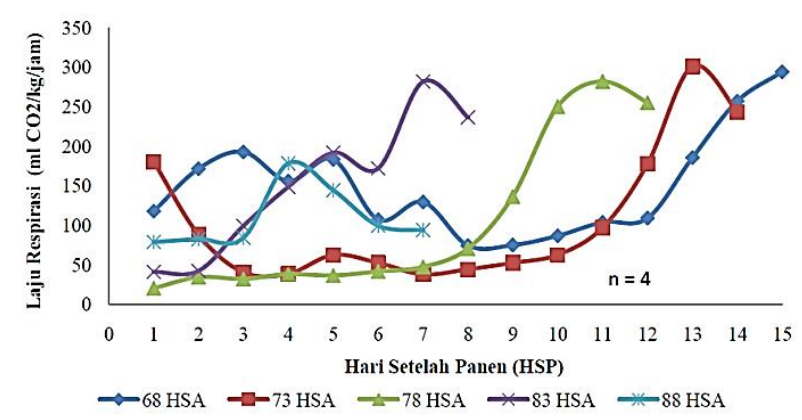

Gambar 2. Laju respirasi pisang Barangan pada beberapa perlakuan umur petik; $n=$ jumlah ulangan pada setiap taraf perlakuan

Buah pisang yang mencapai puncak klimakterik lebih cepat memiliki masa simpannya lebih singkat. Buah pisang dengan perlakuan umur petik 75 HSA mencapai puncak klimakterik pada umur 4 HSP memiliki masa simpan yang lebih rendah dari buah yang diberikan perlakuan umur petik 85, 90, dan 95 HSA. Menurut Widjanarko (2012) masa simpan pisang yang telah mencapai fase klimakterik lebih awal menjadi relatif lebih singkat karena peningkatan laju respirasi dapat meningkatkan laju perombakan bahan kompleks dalam buah. Kitinoja dan Kader (2002) menyatakan bahwa kerusakan mekanis dapat menyebabkan meningkatnya kehilangan kandungan air, peningkatan emisi $\mathrm{CO}_{2}$ dan produksi etilen yang 
berakibat pada cepatnya kemunduran kualitas buah. Menurut Nurjanah (2002) laju respirasi pada buah-buahan dan sayuran dapat dipengaruhi oleh faktor lingkungan seperti temperatur, cendawan, serta faktor internal seperti tipe produk, tingkat perkembangan dan struktur atau asal buah-buahan atau sayuran. Pengaruh aktivitas mikroorganisme penyebab penyakit pascapanen juga dapat mempengaruhi laju emisi $\mathrm{CO}_{2}$ buah. Pantastico (1986) menyatakan umur simpan dapat diperpanjang dengan pengendalian penyakitpenyakit pascapanen, pengaturan atmosfer, perlakuan kimia, penyinaran, dan pendinginan. Proses reduksi etilen dapat mengurangi laju emisi $\mathrm{CO}_{2}$ buah.

Gambar 2 menunjukkan bahwa buah pisang pada setiap perlakuan memiliki laju respirasi yang rendah pada 1 HSP kemudian mulai meningkat beberapa hari setelahnya hingga mencapai puncak klimakterik. Saat buah mulai berubah warna dengan munculnya semburat kuning pada pangkal buah, laju respirasi buah mulai meningkat. Simmonds (1966) menyatakan bahwa laju respirasi (emisi $\mathrm{CO}_{2}$ ) pisang saat berwarna hijau penuh rendah dan cenderung tetap rendah sebelum pisang masak atau mulai menguning. Laju respirasi kemudian meningkat sebelum tanda awal kemasakan dan terus meningkat hingga mencapai puncak klimakterik. Nakasone dan Paull (1998) menyatakan bahwa informasi laju emisi $\mathrm{CO}_{2}$ dan produksi etilen dapat digunakan sebagai sumber acuan dalam menentukan kebutuhan suhu dalam ruang pendingin dan kontainer. Pisang termasuk ke dalam buah dengan emisi $\mathrm{CO}_{2}$ tinggi berkisar 35-70 mg kg-1 $\mathrm{jam}^{-1} \mathrm{CO}_{2}$. Buah dengan emisi $\mathrm{CO}_{2}$ tinggi memiliki masa simpan lebih pendek dibandingkan dengan buah dengan laju emisi $\mathrm{CO}_{2}$ rendah.

Buah pisang dengan perlakuan umur petik 68 dan 73 HSA memiliki umur simpan yang cukup lama, namun terlihat perbedaan laju respirasi pada awal penyimpanan jika dibandingkan dengan laju respirasi pada perlakuan lainnya seperti pada Gambar 6. Buah dengan perlakuan umur petik 68 dan 73 HSA memiliki laju respirasi awal yang lebih tinggi dibandingkan perlakuan lainnya. Terdapat kemungkinan bahwa perlakuan umur petik 68 dan 73 HSA terlalu awal sehingga buah pisang yang dipanen terlalu muda dan belum mencapai puncak kemasakan. Laju respirasi buah yang rendah pada awal masa penyimpanan dapat disebabkan buah yang dipanen terlalu muda. Pantastico (1986) menyatakan bahwa buah yang belum masak memiliki lapisan kutikula yang tipis.

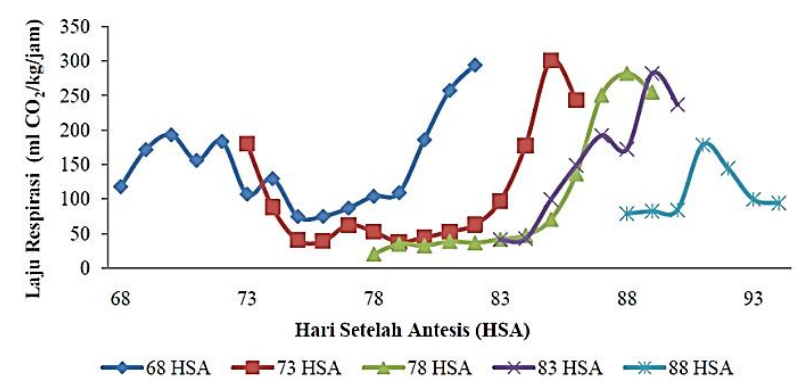

Gambar 3. Laju respirasi pisang Barangan pada beberapa perlakuan umur petik dengan selang waktu 5 hari; $\mathrm{n}=$ jumlah ulangan pada setiap taraf perlakuan

Lapisan ini menjadi tebal setelah buah masak sehingga permeabilitas kulit buah terhadap gas berkurang.

Gambar 3 menunjukkan laju respirasi dengan menggeser grafik setiap perlakuan sesuai dengan selang umur petik. Laju respirasi buah dengan perlakuan umur petik 68-83 HSA terlihat cenderung sejajar. Hal ini dapat disebabkan buah pisang berada pada fase yang sama ketika berada pada titik yang sama. Buah pisang dengan perlakuan umur petik 68 dan 73 HSA memiliki laju respirasi yang tinggi pada awal penyimpanan kemudian menurun hingga mencapai titik terendahnya. Laju respirasi buah pisang dengan umur petik 68 dan 73 HSA pada awal penyimpanan belum mencapai titik terendahnya dapat disebabkan buah tersebut belum mencapai puncak kemasakan saat dipanen. Laju respirasi buah pisang sebelum masak cenderung tinggi dan mencapai titik terendah ketika memasuki fase puncak kemasakan hingga kemudian meningkat kembali pada fase pematangan. Pantastico (1986) menyatakan bahwa laju respirasi buah klimakterik berada pada titik terendahnya ketika berada pada puncak kemasakan dan mulai meningkat hingga berada pada titik tertingginya ketika memasuki fase pematangan.

\section{Kualitas Fisik}

Perubahan pada fisik buah terjadi selama proses pematangan buah. Perubahan mutu fisik buah pisang selama penyimpanan. Kualitas fisik yang diamati antara lain, susut bobot, kekerasan kulit dan daging buah, dan bagian buah yang dapat dimakan (edible part). Hasil analisis mutu fisik pisang Barangan disajikan pada Tabel 2.

Selama proses pematangan terjadi beberapa perubahan diantaranya yaitu perubahan kelunakan buah. Pertambahan tingkat kematangan buah pada umumnya diikuti dengan proses pelunakan kulit dan daging buah. Semakin tinggi nilai kelunakan kulit dan daging buah menunjukkan bahwa buah tersebut semakin lunak. Tabel 2 menunjukkan bahwa perlakuan umur petik mempengaruhi 
Tabel 2. Kualitas fisik pisang Barangan

\begin{tabular}{cccccc}
\hline $\begin{array}{c}\text { Umur Petik } \\
(\text { HSA })\end{array}$ & $\begin{array}{c}\text { Bobot } \\
(\mathrm{g})\end{array}$ & $\begin{array}{c}\text { Kekerasan } \\
\text { Kulit Buah } \\
\left(\mathrm{mm} \mathrm{g}^{-1} \text { detik }^{-1}\right)\end{array}$ & $\begin{array}{c}\text { Kekerasan Daging } \\
\text { Buah }\left(\mathrm{mm} \mathrm{g}^{-1} \text { detik }^{-1}\right)\end{array}$ & $\begin{array}{c}\text { Susut Bobot } \\
(\%)\end{array}$ & $\begin{array}{c}\text { Edible Part } \\
(\%)\end{array}$ \\
\hline 68 & $1128.8 \mathrm{~b}$ & $0.00591 \mathrm{a}$ & 0.016 & $26.7 \mathrm{a}$ & 71.99 \\
73 & $1128.8 \mathrm{~b}$ & $0.00421 \mathrm{~b}$ & 0.016 & $22.1 \mathrm{~b}$ & 70.30 \\
78 & $1557.2 \mathrm{a}$ & $0.00547 \mathrm{ab}$ & 0.015 & $14.8 \mathrm{c}$ & 67.30 \\
83 & $1549.2 \mathrm{a}$ & $0.00636 \mathrm{a}$ & 0.017 & $15.8 \mathrm{c}$ & 70.90 \\
88 & $1557.6 \mathrm{a}$ & $0.00663 \mathrm{a}$ & 0.015 & $18.4 \mathrm{bc}$ & 70.60 \\
\hline
\end{tabular}

Keterangan : Angka yang diikuti huruf berbeda pada kolom yang sama berbeda nyata berdasarkan hasil DMRT pada taraf $\alpha=5 \%$

kelunakan kulit buah pisang Barangan, tetapi tidak mempengaruhi tingkat kelunakan daging buah pisang Barangan. Tingkat kelunakan daging buah pisang Barangan sebesar 0.015-0.017 $\mathrm{mm} \mathrm{g}^{-1}$ detik $^{-1}$. Tingkat kelunakan kulit buah pisang Barangan dengan perlakuan umur petik 73 lebih rendah dari tingkat kekerasan kulit buah dengan perlakuan umur petik 68, 83, dan 88 HSA. Perlakuan umur petik 73 dan 78 menghasilkan buah dengan tingkat kelunakan kulit buah yang tidak berbeda yaitu sebesar 0.00421-0.00547 mm $\mathrm{g}^{-1}$ detik $^{-1}$. Menurut Prabawati et al. (2008) tingkat kekerasan buah dipengaruhi oleh perubahan tekanan turgor yang disebabkan adanya perubahan komposisi dinding sel.Tekstur buah pisang bergantung pada beberapa faktor antara lain jenis varietas tanaman, teknik budidaya, dan prosedur pematangan.

Umur petik mempengaruhi bobot persisir buah pisang Barangan. Bobot persisir buah dengan perlakuan umur petik 78-88 HSA lebih tinggi yaitu sebesar 1 549.2-1557.6 g, sedangkan bobot persisir buah dengan perlakuan umur petik 68 dan 73 HSA hanya sebesar 1128.8 g. Bobot persisir buah dengan perlakuan umur petik 68 dan 73 yang rendah dapat disebabkan buah dipanen sebelum mencapai puncak kemasakan sehingga buah belum mencapai bobot tertingginya. Pantastico (1986) menyatakan bahwa panen pada umur petik lebih awal dari umur petik normal dapat mengurangi bobot hasil hingga lebih dari $10 \%$ meskipun dapat memperpanjang fase praklimakterik buah selama 3-5 hari.

Perlakuan umur petik mempengaruhi persentase susut bobot buah pisang Barangan, namun tidak mempengaruhi persentase bagian buah yang dapat dimakan atau edible part. Persentase susut bobot tertinggi diperoleh pada umur petik 68 HSA yaitu sebesar $26.7 \%$. Perlakuan umur petik 78-88 HSA menghasilkan persentase susut bobot yang tidak berbeda yaitu sebesar 14.8-18.4\%. Perlakuan umur petik 68 HSA menghasilkan buah pisang dengan susut bobot paling tinggi disebabkan buah mengalami proses respirasi yang lebih panjang. Buah tidak mengalami peningkatan bobot setelah dipanen.
Sebaliknya, buah mengalami susut bobot selama masa penyimpanan akibat respirasi buah. Semakin panjang masa penyimpanan, susut bobot buah semakin besar. Nair dan Singh (2003) menyatakan bahwa susut bobot terjadi karena proses respirasi yang berlangsung selama proses pematangan buah sehingga terjadi kehilangan air dari daging buah. Laju respirasi meningkat selama proses pematangan buah sehingga bobot buah terus berkurang.

Persentase edible part buah pisang Barangan sebesar 67.3-71.9\%. Persentase edible part pada semua perlakuan tidak berbeda dapat disebabkan buah berada pada fase yang sama saat pengamatan yaitu saat buah berada pada skala warna 6. Persentase edible part buah pisang berubah selama proses pematangan. Hal yang membedakannya adalah waktu yang dibutuhkan untuk proses pematangan tersebut. Menurut Kuntarsih (2012) persentase bobot daging buah pisang pada awal pembentukan buah sangat rendah. Persentase bobot daging buah pisang bertambah disertaise dikit demi sedikit pengurangan bobot kulitnya selama proses pematangan akibat perubahan selulosa dan hemiselulosa pada kulit buah menjadi zat pati selama proses pematangan. Pantastico (1986) menyatakan bahwa kandungan gula dalam daging buah meningkat dengan cepat selama fase pematangan sehingga tekanan osmotik meningkat dan terjadi penyerapan air dari kulit buah oleh daging buah. Hal ini yang menyebabkan buah pisang yang terlalu matang memiliki kulit buah yang tipis dan daging buahnya berair.

\section{Kualitas Kimia}

Komposisi kimia buah sangat erat kaitannya dengan kualitas buah. Kualitas kimia menjadi salah satu pertimbangan konsumen untuk mengonsumsinya. Hasil analisis mutu kimia pisang Barangan disajikan pada Tabel 3. Umur petik mempengaruhi padatan terlarut total (PTT) buah pisang Barangan (Tabel 3). Kandungan PTT buah pisang dengan umur petik 68 dan 73 HSA lebih tinggi dapat disebabkan kandungan gula yang teroksidasi lebih rendah. Grafik laju respirasi buah 
Tabel 3. Kualitas kimia pisang Barangan pada indeks skala warna 6

\begin{tabular}{ccccc}
\hline Umur Petik (HSA) & Vitamin C (mg/100gbahan) & PTT $\left({ }^{\circ}\right.$ Brix $)$ & ATT $(\%)$ & PTT/ATT \\
\hline 68 & $54.21 \mathrm{a}$ & $29.60 \mathrm{a}$ & $0.64 \mathrm{~b}$ & $46.79 \mathrm{a}$ \\
73 & $39.07 \mathrm{~b}$ & $29.58 \mathrm{a}$ & $0.74 \mathrm{a}$ & $40.28 \mathrm{~b}$ \\
78 & $36.61 \mathrm{~b}$ & $28.14 \mathrm{~b}$ & $0.74 \mathrm{a}$ & $37.87 \mathrm{~b}$ \\
83 & $37.31 \mathrm{~b}$ & $27.40 \mathrm{~b}$ & $0.75 \mathrm{a}$ & $36.63 \mathrm{~b}$ \\
88 & $37.59 \mathrm{~b}$ & $28.53 \mathrm{ab}$ & $0.60 \mathrm{~b}$ & $47.62 \mathrm{a}$ \\
\hline
\end{tabular}

Keterangan : Angka yang diikuti huruf berbeda pada kolom yang sama berbeda nyata berdasarkan hasil DMRT pada taraf $\alpha=5 \%$

pada Gambar 2 menunjukkan bahwa laju respirasi (emisi $\mathrm{CO}_{2}$ ) buah pisang dengan umur petik 68 HSA berhenti sebelum laju respirasinya menurun kembali. Buah pisang dengan perlakuan umur petik 68 HSA mencapai skala warna 6 sebelum laju respirasinya menurun kembali. Proses respirasi buah selama pematangan juga melibatkan perubahan kandungan biokimia dalam buah seperti perombakan pati menjadi gula. Namun setelah proses perombakan pati telah selesai, gula akan digunakan kembali untuk metabolisme buah. Kader (1999) menyatakan bahwa kadar padatan terlarut total meningkat seiring dengan perkembangan buah. Selama proses perkembangan buah terjadi perombakan pati menjadi gula. Menurut Muchtadi et al. (2013) saat proses pemecahan polisakarida menjadi gula sederhana telah selesai, proses respirasi untuk menyediakan energi yang akan digunakan pada metabolisme buah terus berlangsung hingga menyebabkan gula terus teroksidasi. Pantastico (1986) menyatakan bahwa laju emisi $\mathrm{CO}_{2}$ berkurang setelah perombakan pati menjadi gula sederhana selesai dan proses respirasi.

Vitamin C pada buah pisang diukur dengan mengukur kandungan asam askorbat dalam sari buah pisang. Umur petik mempengaruhi kandungan vitamin $\mathrm{C}$ dan asam tertitrasi total (ATT) buah pisang Barangan. Kandungan vitamin C tertinggi terdapat pada perlakuan umur petik 68 HSA yaitu sebesar $54.21 \mathrm{mg} 100 \mathrm{~g}^{-1}$ bahan. Kandungan ATT buah pisang Barangan dengan perlakuan umur petik 68 dan 88 HSA lebih rendah dari kandungan ATT buah dengan perlakuan umur petik 73, 78, dan 83 HSA. Buah pisang mengalami peningkatan jumlah asam selama proses pematangan buah. Kader (1999) menyatakan bahwa total asam yang terkandung dalam buah termasuk asam askorbat cenderung meningkat selama proses pematangan buah karena proses dekarboksilasi asam oksalat. Asam oksalat yang menyebabkan rasa sepat pada buah pisang dirombak oleh enzim oksalat oksidase. Menurut Ilmi et al. (2015) pada buah mangga gedong, suhu simpan dapat menghambat proses perubahan asam organik menjadi senyawa yang lebih sederhana yang menunjukkan bahwa proses respirasi terhambat. Etienne et al. (2014) menyatakan bahwa konsentrasi sitrat dan malat tidak dipengaruhi oleh teknik budidaya tanaman tetapi lebih dipengaruhi oleh genotipe dan umur buah yang dipanen. Wyman dan Palmer (1964) menyatakan bahwa asam malat dan asam sitrat pada buah pisang meningkat 3-4 kali lipat setelah melewati fase pematangan. Pegg et al. (2010) menyatakan bahwa kandungan asam yang dominan dalam buah pisang yaitu asam malat dan asam sitrat dengan perbandingan 3:1.

\section{KESIMPULAN}

Buah pisang Barangan dapat dipanen pada umur 78 HSA dengan akumulasi satuan panas sebesar 1 200-1 $250{ }^{\circ} \mathrm{C}$ hari dan umur simpan mencapai 13-14 HSP. Buah pisang Barangan dengan umur petik lebih tua lebih cepat mencapai kematangan pascapanen dibandingkan buah dengan umur petik muda. Perlakuan umur petik mempengaruhi bobot buah, susut bobot, kekerasan kulit buah, dan mutu kimia, namun tidak mempengaruhi kekerasan daging buah dan edible part.

\section{DAFTAR PUSTAKA}

Bradley, R.L. 2010. Moisture and total solids analysis. In S.S. Nielsen (ed.). Food Analysis Fourth Edition. Springer. New York.

Cahyono, B. 2009. Pisang Usaha Tani dan Penanganan Pascapanen. Kanisius. Yogyakarta.

Etienne, A., M. Génard, D. Bancel, S. Benoit, G. Lemire, C. Bugaud. 2014. Citrate and malate accumulation in banana fruit ( $M u s a$ sp. AA) is highly affected by genotype and fruit age, but not by cultural practices. Hort Sci. 169: 99-110.

Ilmi, N.K., R. Poerwanto, Sutrisno. 2015. Perlakuan air panas dan pengaturan suhu simpan untuk mempertahankan kualitas buah mangga (Mangifera indica L.) cv. gedong. J. Hort. Indonesia 25(1): 78-87. 
Kader, A.A. 1999. Fruit maturity, ripening, and quality relationship. In $\mathrm{L}$. Michalczuck (ed.). Effect of Pre- and Post Harvest Factors on Storage of Fruit. Acta Hort. 485: 203-208.

[Kementan] Kementerian Pertanian. 1995. Produksi Pisang Menurut Provinsi, 20112015. http://www.pertanian.go.id/Data5ta hun/pdf-HORTI2016/2.2 Produksi\%20Pi sang.pdf. [10 Desember 2016].

Kitinoja, L., A.A. Kader. 2002. Praktik-Praktik Penanganan Pascapanen Skala Kecil: Manual untuk Produk Hortikultura Edisi ke-4. Dalam I.M.S. Utama (ed.). Small Scale Postharvest Handling Practices: A Manual for Horticultural Crops (4th Edition). Universitas Udayana. Denpasar.

Kuntarsih, S. 2012. Pedoman Penanganan Pascapanen Pisang. Direktorat Budidaya dan Pascapanen Buah Kementerian Pertanian. Jakarta.

Muchtadi, T.R., Sugiyono, F. Ayustaningwarno. 2013. Ilmu Pengetahuan Bahan Pangan. Alfabeta. Bandung.

Nair, S., Z. Singh. 2003. Pre-storage ethrel dip reduces chilling injury, enchances respiration rate, ethylene production, and improves fruit quality of 'Kensington' mango. Food, Agriculture, \& Environtment. 1(2): 93-97.

Nakasone, H.Y., R.E. Paull. 1998. Tropical Fruit. CAB International. Oxon.

Nurjanah, S. 2002. Kajian laju respirasi dan produksi etilen sebagai dasar penentuan waktu simpan sayuran dan buah-buahan. Jurnal Bionatura Indonesia. 4(3): 148-156.

Pantastico, E.B. 1986. Fisiologi Pasca Panen, Penanganan dan Pemanfaatan Buah-Buahan dan Sayur- Sayuran Tropika dan Subtropika. Dalam Kamariyani (ed.). Postharvest Physiology, Handling and Utilization of Tropical and Sub-Tropical Fruits and Vegetables. Gajah Mada University. Yogyakarta.

Pegg, R.B., W.O. Landen, R.R. Eitenmiller. 2010. Vitamin analysis. In S.S. Nielsen (ed.). Food Analysis Fourth Edition. Springer. New York. 179-200.
Parthasarathi, T., G. Velu, P. Jeyakumar. 2013. Impact of crop heat unit on growth and developmental physiology of future crop production: a review. Research and Reviews: A Journal of Crop Science and Technology. 2(1): 1-11.

Prabawati, S., Suyanti, A.S. Dondy. 2008. Teknologi Pascapanen dan Teknik Pengolahan Buah Pisang. Badan Penelitian dan Pengembangan Pertanian. Bogor.

Pradhana, A.Y., R. Hasbullah, Y.A. Purwanto. 2013. Pengaruh penambahan kalium permanganat terhadap mutu pisang (cv. Mas Kirana) pada kemasan atmosfer termodifikasi aktif. J. Pascapanen Indonesia. 10(2): 83-94.

Prasetyo, M.W.H. 2016. Penentuan waktu panen pisang Mas Kirana berdasarkan satuan panas. [Skripsi]. Institut Pertanian Bogor. Bogor.

Rahayu, M.D., W.D. Widodo, K. Suketi. 2014. Penentuan waktu panen pisang Raja Bulu berdasarkan evaluasi buah beberapa umur petik. J. Hort. Indonesia. 5(2): 65-72.

Santoso, B., B.S. Purwoko. 1995. Fisiologi dan Teknologi Pascapanen Tanaman Hortikultura Indonesia. Indonesia Australia Eastern Universities Project.

Sadler, G.D., P.A. Murphy. 2010. pH and Titratable Acidity. In S.S. Nielsen (ed.). Food Analysis Fourth Edition. Springer. New York. 219-238.

Simmonds, N.W. 1966. Bananas. Longman. London.

Suryana, A. 2006. Peran Teknologi Pascapanen dan Sistem Keamanan Pangan dalam meningkatkan Nilai Tambah Hasil Pertanian. Balai Besar Penelitian dan Pengembangan Pascapanen Pertanian, Jakarta.

Sutowijoyo, D., W.D. Widodo. 2013. Kriteria kematangan pascapanen pisang Raja Bulu dan pisang Kepok. Dalam J.G. Kartika, W.B. Suwarno, S.W. Ardhie, C.P.E. Sanura, F.N. Fitriana (eds.). Membangun Sistem Baru Agribisnis Hortikultura Indonesia pada Era Pasar Global. Prosiding Seminar Ilmiah Perhimpunan Hortikultura Indonesia (PERHORTI). Bogor, 9 Oktober 2013. 
Widjanarko, S.B. 2012. Fisiologi dan Teknologi Pascapanen. UB-Press. Malang.

Wang, J.Y. 1960. A Critique of heat unit approach to plant response studies. Ecology. 41(4): 785-790.

Wyman, H., J.K. Palmer. 1964. Organic acids in the ripening banana fruit. Plant Physiology. 39(4): 630- 633.
Yulyana, E. 2015. Kriteria kematangan pascapanen pisang Mas Kirana (Musa sp. AA Group) berbasis satuan panas. [Skripsi]. Institut Pertanian Bogor. Bogor. 